\title{
Liming and Postharvest Quality of Carambola Fruits
}

\author{
Renato de Mello Prado ${ }^{1 *}$, William Natale ${ }^{1}$, Márcio Cleber de Medeiros Corrêa ${ }^{1}$ and José \\ Antônio Alberto da Silva ${ }^{2}$ \\ ${ }^{I}$ Departamento de Solos e Adubos; Universidade Estadual Paulista - UNESP; FCAV; rmprado@fcav.unesp.br; \\ 14870-000; Jaboticabal - São Paulo - Brasil. ${ }^{2}$ Estação Experimental de Citricultura de Bebedouro; Bebedouro - \\ São Paulo - Brasil
}

\begin{abstract}
To determine the effects of lime application on the postharvest quality of carambola fruit, an experiment with carambola trees cultivated on an acid soil was conducted at the Bebedouro, São Paulo, Brazil. The trees were treated with increasing doses of lime during the pre-planting period. Liming led to a increase in calcium concentration of carambola leaves and fruits. Adequate nutrition of the plant with calcium improved post-harvest fruit quality, permitting a longer ( 2 days) period of storage under ambient conditions.
\end{abstract}

Key words: $\mathrm{Ca}$, lime, storage, Carambola averrhoa, fruit quality

\section{INTRODUCTION}

Improvement in fruit quality has economical implications in the value of the product, as well as in strengthening or expanding of consumer markets. The storage of fruits at low temperatures is one option to preserve their post-harvest quality and to increase the shelf life. However, ice crystals are formed inside the cells during the freezing process, leading to an increased loss of juice and, consequently, nutrients during thawing due to exudation, thus further reducing the content of soluble solids (Bernhardt et al.,1979). In addition, the freezing process requires energy, which affects the final value of the fruit. Another efficient and low- cost technique is the direct application of nutrients to the fruits, with calcium being the most promising and most extensively studied element. Nutrition-related factors are among those affecting the quality of fruits. Use of fertilizers, inch as nitrogen and potassium fertilizers, might affect the absorption of other nutrients such as calcium, reducing its content in the plant and consequently in the fruits, and thus compromising fruit quality. In this respect, researchers studying plant nutrition are facing a great challenge, i.e., to balance production and quality.

About $60 \%$ of the total cell calcium is found in the cell wall (middle lamella) where it exerts a stabilizing function (Tobias et al., 1993), influencing the texture, firmness and maturation of fruits (Hanson et al., 1993), and reducing vitamin $\mathrm{C}$ degradation, ethylene and $\mathrm{CO}_{2}$ production and the incidence of post-harvest diseases (Conway and Sams, 1983). The lack of this element leads to marked membrane deterioration, with alterations in membrane architecture, fluidity and water permeability (Poovaiah, 1986).

Different methods are available to supply calcium to plants, and consequently to fruits. The application of soil acidity-correcting material (lime or steel industry dross) as a source of calcium might be advantageous since it improves the soil's

\footnotetext{
*Author for correspondence
} 
chemical properties, increases the utilization of fertilizers, and guarantees the presence of calcium in the fruits. The immobility of calcium in the phloem requires its constant absorption by the plant through the transpiration system (xylem) and, therefore, leaf application of this element is inefficient in terms of fruit nutrition.

In addition to liming, other options exist to provide the plant with the necessary calcium, such as the direct application of calcium to fruits before or after harvest; however, the efficacy of this practice depends, among other factors, on variables related to the fruit being considered. The results of this technique reported in the literature are contradictory. This treatment had a positive effect on the of post-harvest quality for some fruits such as strawberry (Cheour et al., 1991) and passion fruit (Silva and Vieites, 2000), while no significant effect was observed for jaboticaba (Mota et al., 1997) or guava cv. Kumagai (Carvalho et al., 1998). Repeated applications (up to 4 times) during development of the mango fruit did not show any beneficial effect on fruit quality, probably because there was no increase in calcium concentration in the fruit pulp (Rabelo et al., 1996; Silva and Menezes, 2000).

Therefore, liming is considered to be an efficient technique with long-lasting effects on the maintenance of calcium content in the plant and fruits, and direct effects on the quality of fruits such as carambola. However, no studies are available in the literature regarding the effect of liming applied to carambola trees on the fruit production and quality (Donadio et al., 2001). Thus, the objective of the present study was to determine the effects of the application of increasing lime doses to soil on the quality of firstproduction carambola by monitoring post-harvest alterations in the physicochemical properties of the fruits.

\section{MATERIAL AND METHODS}

This study was carried out at the Bebedouro Experimental Citrus Culture Station, municipality of Bebedouro, SP, Brazil, 20 53'16" South latitude and $48^{\circ} 28^{\prime} 11^{\prime \prime}$ West longitude, at an altitude of 601 $\mathrm{m}$. According to the Köppen classification, the local climate is of the subtropical Cwa type, with short, moderate and dry winters, and hot and rainy summers, characterizing two distinct seasons. The soil is a Typic Hapludox. Before the beginning of the experiment, the composition of 20 soil subsamples collected at depths of 0-20, 20-40 and $40-60 \mathrm{~cm}$ was determined in order to characterize the study site. The results of the chemical analysis for the assessment of fertility are shown in Table 1. The experimental design consisted of random blocks of five treatments and four repetitions. For the treatments, increasing doses of lime were used, considering a base saturation (V) of $70 \%$. The doses were calculated for the $0-30 \mathrm{~cm}$ layer as follows: $D_{0}=$ zero lime, $D_{1}=1,85$ t.ha $^{-1}$ (half the dose necessary to increase $\mathrm{V}$ to $70 \%), \mathrm{D}_{2}=3.79$ t.ha ${ }^{-1}$ (dose necessary to increase $\mathrm{V}$ to $70 \%$ ), $\mathrm{D}_{3}=$ 5.56 t.ha $^{-1}$ (1.5 times the dose necessary to increase $\mathrm{V}$ to $70 \%$ ), and $\mathrm{D}_{4}=7.41$ t.ha $^{-1}$ (twice the dose necessary to increase $\mathrm{V}$ to $70 \%$ ), applied in August 1999. Lime was applied over the entire soil surface and incorporated to a depth of $30 \mathrm{~cm}$. The experimental plots consisted of five grafted carambola trees (cv. Malasia), with the three central trees being used for analysis. Spacing was $7 \mathrm{~m}$ between rows and $4.2 \mathrm{~m}$ between trees. Carambola trees were planted on December 12, 1999 and were submitted to irrigation.

All plants received NPK throughout the year. Basic fertilization consisted of a mixture of $200 \mathrm{~g}$ $\mathrm{P}_{2} \mathrm{O}_{5}, 20 \mathrm{~L}$ organic compost, $1.0 \mathrm{~g} \mathrm{~B}$ and $2.0 \mathrm{~g} \mathrm{Zn}$. Cover fertilization for the first and second year consisted of 140 and $200 \mathrm{~g} \mathrm{~N}$ and 112 and $50 \mathrm{~g}$ $\mathrm{K}_{2} \mathrm{O}$ per tree, respectively.

Table 1 - Chemical properties of the soil in the study area

\begin{tabular}{|c|c|c|c|c|c|c|c|c|c|c|}
\hline Layer & $\begin{array}{c}\mathbf{p H} \\
\mathrm{CaCl}_{2}\end{array}$ & $\begin{array}{l}\text { Organic } \\
\text { matter }\end{array}$ & $\begin{array}{c}\mathbf{P} \\
\text { resin }\end{array}$ & $\mathbf{K}$ & $\mathbf{C a}$ & $\mathrm{Mg}$ & $(\mathrm{H}+\mathrm{Al})$ & SB & $\mathbf{T}$ & $\mathbf{V}$ \\
\hline$(\mathrm{cm})$ & & $\left(\mathrm{g} \mathrm{dm}^{-3}\right)$ & $\left(\mathrm{mg} \mathrm{dm}^{-3}\right)$ & & & $-(n$ & $\left.{ }^{10 l_{c}} \mathrm{dm}^{-3}\right)$ & & & $(\%)$ \\
\hline $0-20$ & 4.7 & 18 & 6 & 1.3 & 9 & 4 & 40 & 14.3 & 54.3 & 26 \\
\hline $20-40$ & 4.4 & 16 & 3 & 0.6 & 6 & 3 & 42 & 9.6 & 51.6 & 19 \\
\hline $40-60$ & 4.4 & 16 & 4 & 0.6 & 7 & 4 & 45 & 11.6 & 56.6 & 20 \\
\hline
\end{tabular}


To evaluate the effect of liming on plant nutrition, leaf calcium content was determined in fully flowering trees by sampling two types of leaves, i.e., the $3 \mathrm{rd}$ and 6 th mature leaf, including the petiole, in flowering branches. Calcium concentration was determined in leaves and fruits according to the method of Bataglia et al. (1983). Fruits (30 per plot) were collected (01 March 2002) when they showed a firm texture and a skin color changing from green to mate, with the beginning of a yellow color formation at the fruit base (Donadio et al., 2001). This time of collection corresponded to the first year of carambola production, by 2-year-old trees.

After collection, the total weight, transverse diameter (axis perpendicular to the length of the fruit in the median part), length (axis between the insertion of the peduncle and the estiolar scar, juice weight, $\%$ juice, soluble solids ( ${ }^{\circ}$ Brix), titratable acidity, and the soluble solid/titratable acidity ratio of the fruits were determined. In addition, loss of fresh mass and fruit firmness were measured daily for 7 days during ambient storage. Total soluble solid content ( $\left({ }^{\circ} \mathrm{Brix}\right)$ of the pulp was measured with a table refractometer (ATAGO-3T). For the determination of total titratable acidity ( $\mathrm{g}$ citric acid per $100 \mathrm{~g}$ pulp), $5 \mathrm{~mL}$ of pulp was titrated with $0.1 \mathrm{~N} \mathrm{NaOH}$ using three drops of $10 \mathrm{~g}$ $\mathrm{L}^{-1}$ phenolphthalein as an indicator, and the results are reported as $\mathrm{g}$ Eq citric acid/100 ml pulp
(Tressler and Joslyn, 1961). Firmness of the pulp (N) was determined with a penetrometer (Model FDV-10) with a 5/16 inch diameter point.

\section{RESULTS AND DISCUSSION}

As a result of the mean lime doses, a linear increase in weight loss and a square reduction in firmness was observed for fruits stored for 7 days (Fig 1). The loss of fresh mass showed a 6-fold increase from the first to the seventh day of storage, while firmness was reduced 1.4 times during the same period. At the end of storage (day 7), weight loss reached $10 \%$. Singh and Chauhan (1982), studying guava (cv. L-49) cultivated in India, observed an $18 \%$ weight loss after 8 days of storage at ambient temperature. These differences were due to variations in climatic conditions and in the fruit species/cultivar used by the authors. This positive correlation between weight loss and days of storage has also been reported for grapes (Castro et al.,1999).

Fruit softening has been attributed to changes that occur in pectin substances cementing the cell wall which are characterized by the solubilization of these substances in the middle lamella (Roe and Bruemmer, 1981).

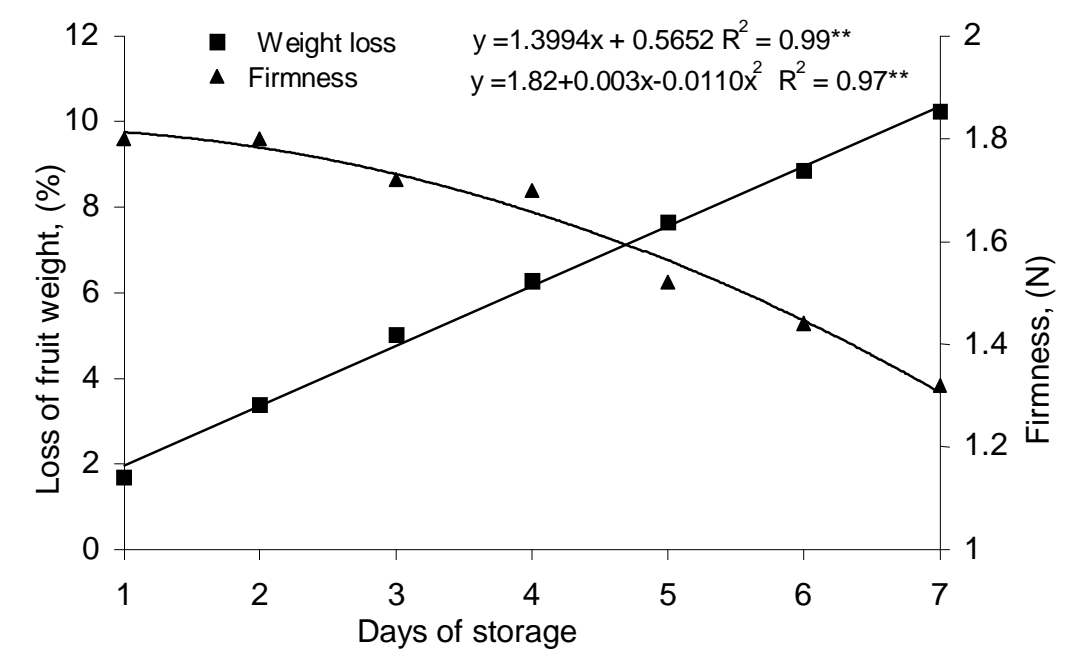

Figure 1 - Effect of days of storage on the loss of weight and firmness of carambola (mean of five lime doses). 
At the beginning, relaxation of the cell wall and hemicellulose degradation are observed, finally followed by pectin depolymerization (Huber et al., 2001), with this process being accelerated when the fruits are stored at ambient temperature. Prati (1999), studying carambola of the sweet and acid types, noted that calcium was effective in maintaining fruit texture during industrial processing, especially in fruits of the sweet type.

Liming did not affect the physical characteristics of the fruits such as total weight, transverse diameter, length or juice weight, but had a significant effect on the percentage of juice and titratable acidity (Table 2). With respect to fruit length and diameter, values of 10.7 to $11.4 \mathrm{~cm}$ and
5.8 to $6.4 \mathrm{~cm}$, respectively, were high when compared to measurements made on carambola in Ceará, with values of 7.74 and $4.51 \mathrm{~cm}$, respectively (Oliveira et al., 1989), and similar to those obtained for cv. Malásia in São Paulo, with mean values of 11.1 and $5.6 \mathrm{~cm}$, respectively (Teixeira et al., 2001).

Although liming increased calcium content in the leaves (Fig 2), it did not affect fruit growth (Table 2). It is known that calcium does not play a major role in cell multiplication but rather in the structure and functioning of membranes. According to Tobias et al. (1993), 60\% of the total cell calcium is found in the cell wall.

Table 2 - Effects of liming on the physicochemical characteristics of carambola fruits during the harvest season. Bebedouro Experimental Citrus Culture Station, SP

\begin{tabular}{|c|c|c|c|c|c|c|c|c|}
\hline $\begin{array}{c}\text { Lime } \\
\text { dose }\end{array}$ & $\begin{array}{c}\text { Fruit } \\
\text { weight }\end{array}$ & $\begin{array}{c}\text { Transverse } \\
\text { diameter }\end{array}$ & $\begin{array}{l}\text { Fruit } \\
\text { length }\end{array}$ & $\begin{array}{c}\text { Juice } \\
\text { weight }\end{array}$ & $\begin{array}{c}\text { Juice } \\
\text { content }\end{array}$ & $\begin{array}{c}\text { Soluble } \\
\text { solids } \\
\end{array}$ & $\begin{array}{c}\text { Titratable } \\
\text { acidity }\end{array}$ & Ratio \\
\hline$\left(\right.$ t.ha $\left.{ }^{-1}\right)$ & (g) & $(\mathbf{c m})$ & $(\mathbf{c m})$ & (g) & $(\%)$ & ('Brix) & (g acid/100 g) & \\
\hline 0 & 124.3 & 5.8 & 10.7 & 69.7 & 55.8 & 9.3 & 0.28 & 33.7 \\
\hline 1.85 & 142.3 & 6.4 & 11.4 & 86.8 & 61.2 & 9.5 & 0.25 & 38.9 \\
\hline 3.79 & 135.8 & 6.1 & 11.2 & 77.1 & 56.7 & 9.9 & 0.25 & 39.2 \\
\hline 5.56 & 122.3 & 5.9 & 10.7 & 70.3 & 57.5 & 10.0 & 0.26 & 39.0 \\
\hline 7.41 & 131.8 & 6.4 & 11.2 & 76.4 & 57.8 & 9.9 & 0.26 & 38.1 \\
\hline F test $\S$ & $0.8^{\mathrm{ns}}$ & $1.5^{\mathrm{ns}}$ & $0.1^{\mathrm{ns}}$ & $1.4^{\mathrm{ns}}$ & $4.1^{*}$ & $2.1^{\mathrm{ns}}$ & $4.0^{*}$ & $2.4^{\mathrm{ns}}$ \\
\hline C.V. $(\%)$ & 14.4 & 7.8 & 6.0 & 15.6 & 3.5 & 4.8 & 4.9 & 8.0 \\
\hline
\end{tabular}

$\S \mathrm{F}$ test $(\mathrm{P}<0.05) ;{ }^{\mathrm{ns}}, *$ - nonsignificant and significant at the $5 \%$ level of probability; ratio $=$ soluble solid/titratable acidity ratio

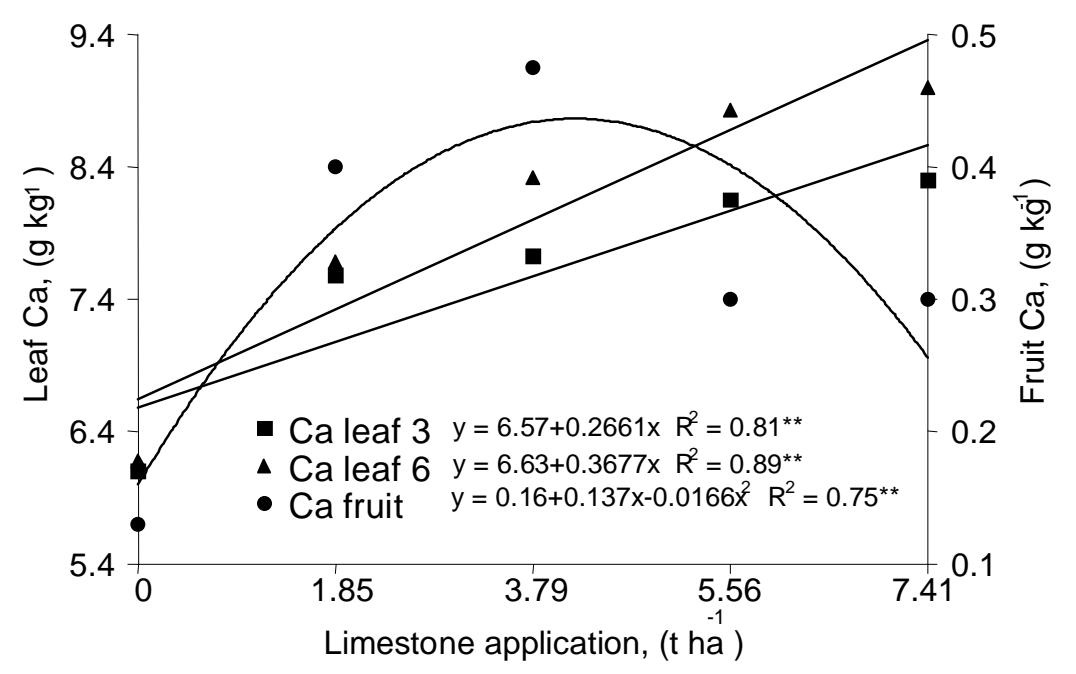

Figure 2 - Effect of the application of lime on the calcium content in the leaves (3rd and 6th) and pulp of carambola (mean of four repetitions). 
The values obtained in the present study for soluble solids ( 9.3 to $10.0^{\circ}$ Brix) were greater than the pattern classified as sweet by Joseph and Mendonça (1989), which was 4 to $8^{\circ}$. Mikami et al. (2000) also did not observe any favorable influence of calcium or magnesium application to soils on the mean weight of guava fruits (cv. Paluma).

The application of lime significantly reduced titratable acidity and increased althongh not significantly, the content of total soluble solids and the soluble solid/titratable acidity ratio. This ratio was between 33 and 39, a value corresponding to that necessary for desirable fruit quality according to Knight Jr. (1989) (ratio >10). The increase in this ratio (from 33.7 to 39.2) could be explained by the decrease in acidity, indicating that the application of lime to the orchard resulted in sweeter fruits.

In guava, the technique of calcium application to fruits did not have any significant effect on their general chemical characteristics (Amen, 1987) or the soluble solid/titratable acidity ratio (Giannoni, 2000). The higher acidity observed for the control treatment (without lime) in the present study might be due to increased degradation of ascorbic acid (Khedkar et al., 1982), or even to a concentration effect in the fruits as a result of greater moisture loss (Adsule and Tandon, 1983), since these plants did not receive any calcium application.

Analysis of the effect of the different lime doses on each day of storage showed a significant difference in the fresh mass of the fruits from the third day of storage (Table 3), and in firmness on day third and after the fifth day (Table 4). These beneficial effects of liming on the post-harvest quality of carambola in terms of loss of fresh mass and firmness can be explained by the known role of calcium in fruit quality. The application of lime provided $\mathrm{Ca}$ to the plants, increasing its concentration in leaves and fruits (Fig. 2). This increase in calcium content as a consequence of liming was linear for the two types of leaves and quadratic for fruits. However, the regression coefficient of the line was higher for the $6^{\text {th }}$ leaf $(0.89)$ than for the $3^{\text {rd }}$ leaf $(0.81)$. This finding might indicate that the 6th leaf is could be bether for foliar diagnosis of carambola trees; however, specific studies involving other nutrients would be necessary to confirm this hypothesis.

The application of lime significantly reduced the loss of fresh mass from the third day of storage, with fruits from the control plots showing a $11.7 \%$ weight loss on the last day compared to $8.2 \%$ for fruits receiving liming (Table 3 ). In addition, the differences between control and liming-treated fruits increased during storage (up to a certain point), ranging from $2 \%$ on day 4 to $3.5 \%$ on day 7. This indicate that the beneficial effects of liming on the post-harvest preservation of fruits were more effective the longest storage period.

Since no field studies on carambola trees were available in the literature, the present results were compared to those reporting the post-harvest application of calcium to other fruits. No significant effect of calcium application on the reduction of fresh mass losses was observed for guava cv. Kumagai (Carvalho et al., 1998) or strawberry (Peter, 2001). In contrast, other studies have shown a difference in fresh mass loss between fruits treated with calcium and untreated control fruits, which reached $2 \%$ for guava cv. Sardar (Singh et al., 1981) and $0.2 \%$ for guava cv. Kumagai (Giannoni, 2000).

With respect to the effect of lime on the firmness of carambola, a significant increase was observed on the third day and from the fifth day of storage (Table 4). These findings on firmness might be explained, as mentioned earlier, by the role of calcium in the rigidity of skin tissue and, consequently, in the decreased loss of water from the fruit (Table 3), and even in the reduction of respiratory rate, protein degradation and the presence of opportunistic microorganisms (Bangerth et al., 1972). The results were in agreement with those reported by Baldawi et al. (1981) who observed that calcium nutrition of fruit trees was frequently associated with firmness of the harvested fruits.

The decrease in firmness of fruits with increasing storage time was in agreement with Chitarra and Chitarra (1994), who stated that firmness (or texture) was strictly related to the solubilization of pectin substances, with the conversion of insoluble into soluble pectin. 
Table 3 - Effects of liming on the loss of fresh mass of carambola during storage. Bebedouro Experimental Citrus Culture Station, SP

\begin{tabular}{lccccccc}
\hline \multicolumn{1}{c}{ Lime dose } & $\mathbf{7}$ & \multicolumn{7}{c}{ Days of storage } \\
& $\mathbf{1}$ & $\mathbf{2}$ & $\mathbf{3}$ & $\mathbf{4}$ & $\mathbf{5}$ & $\mathbf{6}$ & $\mathbf{7}$ \\
\hline \multicolumn{1}{c}{ t.ha $^{-1}$} & & & \multicolumn{7}{c}{ Loss of fresh mass (\%) } \\
0 & 1.6 & 3.3 & 5.1 & 6.9 & 8.3 & 9.7 & 11.7 \\
1.85 & 1.9 & 3.9 & 5.6 & 7.2 & 8.8 & 10.2 & 11.5 \\
3.79 & 1.6 & 3.5 & 5.0 & 6.3 & 7.7 & 8.9 & 10.1 \\
5.56 & 1.9 & 3.5 & 4.9 & 6.0 & 7.2 & 8.8 & 9.6 \\
7.41 & 1.4 & 2.7 & 4.6 & 4.9 & 6.2 & 7.1 & 8.2 \\
\hline F test $\S$ & $1.3^{\text {ns }}$ & $1.9^{\text {ns }}$ & $1.7^{\text {ns }}$ & $3.5^{*}$ & $4.3^{*}$ & $4.8^{*}$ & $5.1^{*}$ \\
\hline C.V. $(\%)$ & 23.1 & 18.6 & 18.0 & 15.3 & 12.9 & 11.9 & 12.7 \\
\hline
\end{tabular}

$\S \mathrm{F}$ test ${ }^{\mathrm{ns}}$ and $*$ - nonsignificant and significant at the $5 \%$ level of probability

Table 4 - Effects of liming on the firmness of carambola during storage. Bebedouro Experimental Citrus Culture Station, SP

\begin{tabular}{|c|c|c|c|c|c|c|c|c|}
\hline \multirow{2}{*}{$\begin{array}{l}\text { Lime } \\
\text { dose }\end{array}$} & \multicolumn{8}{|c|}{ Days of storage } \\
\hline & $\mathbf{0}$ & 1 & 2 & 3 & 4 & 5 & 6 & 7 \\
\hline t.ha $^{-1}$ & \multicolumn{8}{|c|}{ Firmness $(\mathbf{N})$} \\
\hline 0 & 1.8 & 1.8 & 1.6 & 1.5 & 1.6 & 1.3 & 1.1 & 1.1 \\
\hline 1.85 & 1.8 & 1.7 & 1.7 & 1.7 & 1.6 & 1.4 & 1.3 & 1.3 \\
\hline 3.79 & 1.7 & 1.8 & 1.8 & 1.7 & 1.7 & 1.7 & 1.5 & 1.2 \\
\hline 5.56 & 1.8 & 1.8 & 1.9 & 1.7 & 1.8 & 1.8 & 1.8 & 1.4 \\
\hline 7.41 & 1.9 & 1.9 & 2.0 & 2.0 & 1.8 & 1.4 & 1.5 & 1.6 \\
\hline F test & $0.6^{\mathrm{ns}}$ & $1.0^{\mathrm{ns}}$ & $2.7^{\mathrm{ns}}$ & $4.1^{*}$ & $2.2^{\mathrm{ns}}$ & $5.8 * *$ & $9.8 * *$ & $4.4^{*}$ \\
\hline C.V. (\%) & 9.3 & 9.3 & 9.2 & 9.0 & 8.0 & 11.7 & 11.3 & 11.8 \\
\hline
\end{tabular}

ns, *, ** - nonsignificant, and significant at the $5 \%$ and $1 \%$ levels of probability

Giannoni (2000) and Lima and Durigan (2002) did not observe a positive response of guava fruit firmness to calcium application. With respect to post-harvest management, firmness is essential since firmer fruits are more resistant to the mechanical injury that occurs during transport and commercialization.

\section{CONCLUSIONS}

The results obtained in this study showed that liming led to a increase of calcium in the leaves and fruits of the carambola tree. Adequate nutrition of the plant with calcium improved postharvest fruit quality, permitting a longer period of storage under ambient conditions.

\section{ACKNOWLEDGEMENTS}

This work was supported by FAPESP - Fundação de Amparo à Pesquisa do Estado de São Paulo through a fellowship to the senior author (process 00/00758-0, DR).

\section{RESUMO}

Tendo como objetivo avaliar os efeitos da aplicação de doses crescentes de calcário ao solo, na qualidade de frutos de caramboleira pela avaliação das alterações físico-químicas dos frutos após a colheita, foi instalado um experimento em Bebedouro-SP,Brasil, sobre um Latossolo Vermelho distrófico, ácido. Os tratamentos foram doses crescentes de calcário, em pré-plantio, como segue: $\mathrm{D}_{0}=$ zero; $\mathrm{D}_{1}=$ metade da dose; $\mathrm{D}_{2}=\mathrm{a}$ dose; $D_{3}=1,5$ vez a dose; e $D_{4}=2$ vezes a dose para elevar $\mathrm{V}=70 \%$. No florescimento da caramboleira, avaliou-se o teor de cálcio na folha. Após a colheita dos frutos, determinou-se o teor de cálcio na polpa, o peso dos frutos, diâmetro transversal, comprimento, peso da polpa, \% de polpa, ${ }^{\circ}$ Brix, acidez titulável e Ratio dos frutos. Diariamente, durante sete dias de armazenamento em condições ambiente, determinou-se a perda de 
massa fresca e a firmeza dos frutos. A calagem proporcionou um aumentou linear de cálcio nas folhas e nos frutos da caramboleira. A nutrição adequada da planta com cálcio melhorou a qualidade dos frutos pós-colheita, permitindo um período de armazenamento mais longo ( 2 days), em condições ambiente.

\section{REFERENCES}

Amen, K. I. A. (1987), Effect of post-harvest calcium treatments on the storage life of guava fruits. Assist Journal of Agricultural Science, 18, 127-131.

Baldawi, A. M.; Sweiden, A. M.; Fayek, M. A. and ELHawary, A. H. I. (1981), Effect of B, Zn and Ca on growth, fruit quality and storage ability of Le Conte pear. Faculty of Agriculture, Ain Shams University: Egypt.

Bangerth, F.; Dilley, D. R. and Dewey, D. H. (1972), Effects of post-harvest calcium treatments on internal breakdown and respiration of apple fruits. Journal of the American Society for Horticultural Science, 97, 679-682.

Bataglia, O. C.; Furlani, A. M. C.; Teixeira, J. P. F.; Furlani, P. R. and Gallo, J. R. (1983), Métodos de análise química de plantas. Campinas: Instituto Agronômico, 48 pp. (Boletim Técnico, 78).

Bernhardt, L. W.; Tocchini, R. P. and Paschoalino, J. E. (1979), Mudanças que ocorrem durante o armazenamento de frutas e hortaliças congeladas. Boletim do Instituto de Tecnologia de Alimentos, 16, 9-34.

Carvalho, H. A.; Chitarra, M. I. F.; Chitarra, A. B. and Menezes, J. B. (1998), Eficiência da concentração de cloreto de cálcio e do tempo de imersão no tratamento pós-colheita de goiaba de polpa branca cv. Kumagai. Revista Brasileira de Fruticultura, 20, 375-381.

Castro, J. V., Park, K. J. and Honório, S. L. (1999), Utilização de embalagens na conservação de uvas "Red globe". Revista Brasileira de Fruticultura, 21, 150-155.

Cheour, F.; Willwmot, C.; Arul, J.; Makhlouf, J. and Desjardins, Y. (1991), Postharvest response of two Strawberry cultivars to foliar application of $\mathrm{CaCl}_{2}$. Hortscience, 26, 1186-1188.

Chitarra, M. I. F. and Chitarra, A. D. (1994), Póscolheita de frutas e hortaliças: fisiologia e manuseio. Lavras: FAEPE. 293 pp.

Conway, W. S. and Sams, C. E. (1983), Calcium infiltration of Golden Delicious apples and its effect on decay. Phytopathology, 73, 1068-1071.

Donadio, L. C.; Silva, J. A. A.; Araújo, P. R. S. and Prado, R. M. (2001), Caramboleira (Averrhoa carambola L.). Jaboticabal: Sociedade Brasileira de Fruticultura. $81 \mathrm{pp}$.
Garcia, J. L. M. (1978), Matéria prima. In: Medina, J. C.; Garcia, J. L. M.; Kato, K.; Martin, Z. J.; Vieira, L. F. and Renesto, O. V. (Eds.). Goiaba: da cultura ao processamento e comercialização. pp. 47-59. (ITAL: São Paulo, Brazil)

Giannoni, J. A. (2000), Efeito da radiação gama e do cálcio na conservação pós-colheita da goiaba branca armazenada sob refrigeração. Master's thesis, Faculdade de Ciências Agrárias, Universidade Estadual Paulista, Brazil.

Hanson, E. J.; Beggs, J. L. and Beaudry, R. M. (1993), Applying calcium chloride postharvest to improve highbush blueberry firmness. HortScience, 28, 1033-1034.

Huber, D. J.; Karakurt, Y. and Jeong, J. (2001), Pectin degradation in ripening and wounded fruits. Revista Brasileira de Fisiologia, 13, 224-241.

Joseph, J. G. and Mendonça, G. (1989), Chemical characteristics of Averrhoa carambola L. Proceeding of the Interamerican Society of the Tropical Horticulture. Homestead, 33, 121-126.

Khedkar, D. M.; Ansarwadkar, K. W.; Dabhade, R. S. and Ballal, A. L. (1982), Extension of storage life of guava var.L-49. Indian Food Packer, 36, 49-52.

Knight Jr., R. J. (1989), Carambola cultivars and improvement programmes. Proceeding of the Interamerican Society of the Tropical Horticulture, 33, 72-78.

Lima, M. A. and Durigan, J. F. (2002), Reguladores vegetais na conservação pós-colheita de goiabas 'Paluma'. Rev. Bras. Fruticultura, 24, 370-375.

Mikami, E. E.; Pintro, J. C.; Tormena, C. A.; Costa, A. C. S. and Sengik, E. (2000), Influência da aplicação de cálcio, de magnésio e de potássio no solo sobre a produção de goiaba (Psidium guajava L.) cv. Paluma. Acta Scientiarum, 22, 1075-1081.

Mota, W. F.; Salomão, L. C. C.; Pereira, M. C. T.; Vieira, G. and Finger, F. L. (1997), Influência do tratamento pós-colheita com cálcio na conservação de jabuticabas. In: Congresso Brasileiro de Fisiologia Vegetal, 6., Belém. Procedings... pp. 247. Belém: Sociedade Brasileira de Fisiologia Vegetal.

Natale, W.; Coutinho, E. L. M.; Boaretto, A. E. and Pereira, F. M. (1996), Goiabeira: calagem e adubação. Jaboticabal: FUNEP.

Oliveira, M. N.; Maia, G. A.; Guedes, Z. B. L.; Guimarães, A. C. L. and Figueiredo, R. W. (1998), Estudo das características físicas e do rendimento da carambola (Averrhoa carambola L.). Ciência Agronômica, 20, 97-99.

Peter, M. A. (2001), Effect of preharvest $\mathrm{CaCl}_{2}$ spray on the postharvest quality of "Rainier" and "Totem" strawberries. Acta Horticulturae, 564, 159-163.

Poovaiah, B. W. (1986), Role of calcium in prolonging storage life of fruits and vegetables. Food Technology, 40, 86-89. 
Prati, P. (1999), Avaliação de carambola (Averrhoa carambola L.) dos tipos doce e ácido, para o processamento de fruta em calda. Master's thesis, Escola Superior "Luiz de Queiroz". USP, Brazil.

Rabelo, J. E. S.; Silva, M. M.; Gaspar, J. W. and Couto, F. A. A. (1996), Efeito da aplicação foliar de cloreto de cálcio e ácido bórico sobre o "colapso interno" da manga "Tommy Altkins". In Manga: tecnologia de produção e mercado. (Eds São José AR, Souza IVB, Martins Filho J, Morais OM). pp. 136-138. (DFZ/UESB:Vitória da Conquista).

Roe, B. and Bruemmer, J. H. (1981), Changes in pectin substances and enzymes during ripening and storage of "Keitt" mangoes. Journal of Food Science, 46, 186-189.

Silva, A. P. and Vieites, R. L. (2000), Tratamento póscolheita com cloreto de cálcio aplicado por infiltração, nas características físicas do maracujazeiro. Revista Brasileira de Fruticultura, 22, 73-76.

Silva, A. V. C. and Menezes, J. B. (2000), Qualidade de manga "Tommy atkis"submetida a aplicação précolheita de cloreto de cálcio. Revista Brasileira de Fruticultura, 22, 86-90.
Singh, K. and Chauhan, K. S. (1982), Effect of certain post-harvest treatments on storage life of cv. L-49 of guava. Haryana Journal of Horticultural Science, 11, 163-167.

Singh, R. V.; Joshi, M. C.; Ram, H. B. and Bishi, N. S. (1984), Effect of waxcoating and prepackaging on the storage behaviour of guava cv. Allahabad Safeda. Indian Food Packe, 38, 80-85.

Teixeira, G. H. A.; Durigan, J. F.; Donadio, L. C. and Silva, J. A. A. (2001), Caracterização pós-colheita de seis cultivares de carambola (Averrhoa carambola L.). Revista Brasileira de Fruticultura, 23, 546-550.

Tobias, R. B., Conway, W. S. and Sams, C. E. (1993), Cell wall composition of calcium-treated apples inoculated with Botrytis cinera. Phytochemistry, 32, 35-39.

Tressler, D. and Joslyn, M. (1961), Fruits and vegetables juice - processing technology. Westport. AVI Publications, 1961. 1028 pp.

Received: March 19, 2004; Revised: September 22, 2004; Accepted: May 24, 2005 